\title{
PENGEMBANGAN PEMBELAJARAN KARAKTER BERBASIS SOFT SKILLS DI PERGURUAN TINGGI ${ }^{1}$
}

\begin{abstract}
Abdullah Aly
Dosen Prodi PAI FAI dan Magister Hukum Islam Sekolah Pascasarjana UMS

Fakultas Agama Islam, Universitas Muhammadiyah Surakarta

e-mail: aa130@ums.ac.id

Abstrak: Perhatian tersebut dilatarbelakangi oleh fakta bahwa pembelajaran di perguruan tinggi Indonesia dalam pengamatan mereka lebih banyak menekankan pada dimensi hard skills dari pada soft skills. Kajian ini menghasilkan dua simpulan penting. Pertama, para dosen dapat menggunakan soft skills untuk mengembangkan karakter lulusan perguruan tinggi lewat kegiatan kemahasiswaan, dengan dua alternatif teori, yaitu: (1) teori nilai pendidikan karakter yang dikemukakan oleh Thomas Lickona atau Pusat Kurikulum Kementerian Pendidikan dan Kebudayaan RI; serta (2) teori jenis soft skills dan bentukbentuknya yang dikemukakan oleh Illah Sailah, baik yang bersifat personal, intra personal atau gabungan dari keduanya
\end{abstract}

Kata Kunci: Pembelajaran Karakter, Soft Skill, Perguruan Tinggi

\section{Pendahuluan}

Pembelajaran karakter di perguruan tinggi belakangan ini telah menjadi perhatian penting dari para pengamat dan pakar pendidikan di Indonesia. Perhatian tersebut dilatarbelakangi oleh fakta bahwa pembelajaran di perguruan tinggi Indonesia dalam pengamatan mereka lebih banyak menekankan pada dimensi hard skills dari pada soft skills. Dalam pandangan mereka, praktik pembelajaran di perguruan tinggi di Indonesia yang ideal itu perlu memadukan antara dimensi hards skills dan soft skills. Jika dimensi hards skills menekankan pada pemberian keterampilan teknis dan akademis para mahasiswa terkait dengan bidang ilmu yang dipelajari, maka dimensi soft skills lebih mengutamakan keterampilan intra dan inter personal para mahasiswanya. Ringkasnya, kedua dimensi tersebut idealnya harus menjadi praktik dalam kegiatan kemahasiswaan dan dalam proses perkuliahan sehari-hari di perguruan tinggi di Indonesia.

Namun demikian, fakta yang terjadi adalah adanya kesenjangan antara yang ideal dan yang riil. Adapun fakta riilnya adalah bahwa praktik pembelajaran karakter di perguruan tinggi di Indonesia selama ini masih sangat memprihatinkan. Hal ini disebabkan oleh adanya kecenderungan dari para dosen yang mengelola proses perkuliahannya kurang memperhatikan dimensi soft skills para mahasiswanya. Sebagai salah satu contoh adalah bahwa para dosen pada saat mengelola perkuliahan di kelas mereka cenderung menekankan pada pemberian keterampilan teknis dan akademis para mahasiswa. Sementara itu, dimensi soft skillsnya yang lebih mengutamakan keterampilan intra dan inter personal kurang memperoleh perhatian dari para dosen. Fakta initidak berdiri sendiri, melainkan merupakan hasil dari fakta lain yang ada di dunia kerja. Pada saat proses perekrutan karyawan baru, misalnya, dunia kerja cenderung menuntut persyaratan yang terkait dengan keterampilan teknis seperti daftar riwayat hidup, indeks prestasi, pengalaman kerja dan berbagai keterampilan yang dikuasai. Dengan demikian, pembelajaran karakter di perguruan tinggi di Indonesia masih sangat

1 Disampaikan pada Diskusi “Seton” dosen PAI UMS pada tanggal 17 Desember 2016

40 I ishraqi, Volume 1 No. 1 Januari 2017 ... (40-51) 
memprihatinkan, karena penekanannya lebih pada dimensi hard skills saja.

Terkait dengan adanya kesenjangan antara yang ideal dan yang riil dalam konteks pembelajaran karakter di atas, Pemerintah RI di bidang pendidikan tinggi telah mencanangkan tiga strategi pengembangan perguruan tinggi di Indonesia. Ketiga strategi tersebut adalah Nation Competitivness, Autonomy, dan Organization Health (Ditjen Dikti, 2004: 5-6). Sebagai salah satu strategi pemerintah, strategi nation competitiveness merupakan salah satu strategi yang sangat relevan untuk memperpendek jarak kesenjangan antara yang ideal dan yang riil dalam konteks pembelajaran karakter di perguruan tinggi di Indonesia dewasa ini.

Memperhatikan uraian di atas, maka rumusan masalah yang ingin dijawab dalam tulisan ini meliputi dua masalah. Pertama, bagaimana para dosen dapat menggunakan soft skills untuk mengembangkan karakter lulusan perguruan tinggi lewat kegiatan kemahasiswaan? Kedua, bagaimana para dosen dapat menjadikan soft skills sebagai basis pembelajaran karakter di perguruan tinggi? Terkait dengan kedua rumusan masalah tersebut, maka tulisan ini bertujuan untuk menguji kemungkinan soft skills digunakan oleh para dosen sebagai basis pengembangan karakter para mahasiswa di perguruan tinggi. Selain itu, tulisan ini juga bertujuan untuk menjadikan soft skills sebagai basis pembelajaran karakter di perguruan tinggi oleh para dosen. Berdasarkan pada rumusan masalah dan tujuan di atas, maka nilai manfaat dari tulisan ini adalah bahwa pembelajaran karakter di perguruan tinggi di Indonesia ke depan dapat dicapai dengan memadukan antara dimensi hard skills dan soft skills dalam satu paket yang terintegrasi-baik dalam kegiatan kemahasiswaan maupun dalam proses perkuliahan sehari-hari.

\section{Metode Kajian}

Bentuk kajian yang digunakan dalam studi ini adalah studi kasus, yaitu pembelajaran karakter berbasis soft skills di perguruan tinggi. Bentuk kajian ini dipilih dengan alasan utama bahwa studi kasus merupakan bentuk kajian yang sangat cocok untuk mengkaji sesuatu peristiwa atau situasi dengan lebih mendalam, dan untuk mendapatkan pemahaman yang lebih komprehensif tentang aspek individu, peristiwa, atau situasi (Creswell, 2008: 19). Menurut Lisa M. Given (2008: 68), studi kasus cocok digunakan untuk mendeskripsikan tentang pandangan, penemuan, dan penafsiran terhadap sesuatu situasi, peristiwa, program, atau fenomena. Selanjutnya, studi kasus dapat memberikan data yang kaya dan informasi yang mendalam, lengkap, menyeluruh, dan dapat memberi gambaran yang lebih terperinci tentang fenomena yang dikaji.

Kajian ini dilakukan dengan menggunakan studi kepustakaan, yaitu kajian teoritis, referensi serta literatur ilmiah lainnya yang berkaitan dengan budaya, nilai dan norma yang berkembang pada situasi sosial yang diteliti (Sugiyono, 2012). Dari buku-buku referensi diperoleh cara pemecahan masalah berdasarkan teoriteori dan rumus-rumus yang telah diuji kebenarannya dan diakui secara umum. Juga dapat ditelaah penelitian-penelitian sebelumnya yang berkaitan dengan objek yang sedang diteliti melalui jurnal ilmiah yang sangat mudah diakses.

Dari segi pengumpulan data, kajian ini menggunakan metode telaah dokumen, yaitu "telaah terhadap catatan peristiwa yang sudah berlalu yang berbentuk tulisan, gambar, atau karya-karya monumental dari seseorang" (Sugiyono, 2012: 329). Metode ini dipilih karena studi dokumen pada masa kini menjadi salah satu bagian yang penting dan tak terpisahkan dalam metodologi penelitian kualitatif. Hal ini disebabkan oleh adanya kesadaran dan pemahaman baru yang berkembang di para peneliti, bahwa banyak sekali data-data yang tersimpan dalam bentuk dokumen dan artefak. Sehingga penggalian sumber data lewat studi dokumen menjadi pelengkap bagi proses penelitian kualitatif. Bahkan tingkat kredibilitas suatu 
hasil penelitian kualitatif sedikit banyaknya ditentukan pula oleh penggunaan dan pemanfaatan dokumen yang ada.

Analisis data dalam kajian ini menggunakan analisis isi (content analysis document), yaitu: "teknik yang digunakan untuk menarik kesimpulan melalui usaha menemukan karakteristik pesan, dan dilakukan secara objektif, dan sistematis" (Moleong, 2007: 220). Tahapannya terdiri atas empat langkah, yaitu: (1) melakukan coding terhadap istilah-istilah atau kalimat yang relevan; (2) mengklasifikasi coding dengan melihat satuan makna yang berhubungan dengan tujuan penelitian dalam rangka membuat kategori; (3) satuan makna dan kategori dianalisis dan dicari hubungan satu dengan lainnya untuk menemukan arti, makna dan tujuan isi dari teks; serta (4) hasil analisis dideskripsikan dalam bentuk draf laporan penelitian.

\section{Kajian Teori}

\section{Definisi Pendidikan Karakter dan Nilai-nilainya}

Pentingnya pendidikan karakter di perguruan tinggi di Indonesia mengacu kepada UU Sisdiknas No 20 Tahun 2003. Dalam UU ini dinyatakan bahwa tujuan pendidikan nasional adalah mengembangkan potensi peserta didik untuk memiliki kecerdasan, kepribadian dan akhlak mulia. Lalu, apa pendidikan karakter itu?

Pendidikan karakter didefinisikan oleh para pakar pendidikan secara beragam. Sebagai contoh John W. Santrock (2007: 121), mengatakan bahwa "pendidikan karakter merupakan pendekatan langsung untuk pendidikan moral dengan memberi pelajaran kepada peserta didik tentang pengetahuan moral dasar untuk mencegah mereka melakukan perilaku tidak bermoral atau membahayakan bagi diri sendiri maupun orang lain". Thomas Lickona menawarkan definisi lain, "pendidikan karakter merupakan suatu usaha yang dilakukan dengan sengaja untuk membantu seseorang sehingga ia dapat memahami, memperhatikan dan melakukan nilai-nilai etika yang pokok" (Lickona, 1991: 51). Sementara itu, menurut Suyanto (2010), "pendidikan karakter sebagai cara berpikir dan berperilaku yang menjadi ciri khas tiap individu untuk hidup dan bekerja sama, baik dalam lingkup keluarga, masyarakat, bangsa, maupun negara". Lebihlanjut, T. Ramli(2003) berpendapat bahwa "pendidikan karakter memiliki esensi dan makna yang sama dengan pendidikan moral dan pendidikan akhlak".

Berdasarkan beberapa definisi di atas ditemukan 4 (empat) hal penting dalam pendidikan karakter. Pertama, pendidikan karakter itu sama dengan pendidikan moral dan pendidikan akhlak. Kedua, pendidikan karakter itu bertujuan untuk membentuk pribadi peserta didik supaya menjadi manusia yang baik, warga masyarakat dan warga negara yang baik. Ketiga, pendidikan karakter itu mengandung tiga unsur pokok, yaitu mengetahui kebaikan, mencintai kebaikan, dan melakukan kebaikan. Keempat, karakter peserta didik dapat dipengauhi oleh guru lewat keteladanannya, seperti cara guru berbicara atau menyampaikan materi, cara guru bertoleransi, dan berbagai hal terkait lainnya.

Matrik 1. Perbandingan Nilai Pendidikan Karakter Menurut Lickona dan Puskur Kemendikbud RI

\begin{tabular}{ll}
\hline Pendapat & \multicolumn{1}{c}{ Nilai Pendidikan Karakter } \\
\hline \multirow{3}{*}{ Thomas Lickona } & 1. Ketulusan hati atau kejujuran, \\
& 2. Belas kasih, \\
& 3. Kegagahberanian, \\
& 4. Kasih sayang, \\
& 5. Kontrol diri, \\
& 6. Kerja sama, \\
7. Kerja keras.
\end{tabular}

42 I ishraqi, Volume 1 No. 1 Januari 2017 ... (40-51) 


\begin{tabular}{ll}
\hline \multicolumn{1}{c}{ Pendapat } & \multicolumn{1}{c}{ Nilai Pendidikan Karakter } \\
\hline & \\
1. $\begin{array}{l}\text { Beriman dan bertakwa, jujur, amanah, adil, tertib, taat aturan, } \\
\text { bertanggung jawab, berempati, berani mengambil resiko, pantang } \\
\text { menyerah, rela berkorban, dan berjiwa patriotik; }\end{array}$ \\
2. $\begin{array}{l}\text { Cerdas, kritis, kreatif, inovatif, ingin tahu, produktif, berorientasi } \\
\text { Ipteks, dan reflektif; }\end{array}$ \\
3. $\begin{array}{l}\text { Bersih, sehat, sportif, tangguh, andal, berdaya tahan, bersahabat, } \\
\text { kooperatif, determinatif, kompetitif, ceria, dan gigih; serta }\end{array}$ \\
4emendikbud RI \\
4emanusiaan, saling menghargai, gotong royong, kebersamaan, \\
ramah, hormat, toleran, nasionalis, peduli, kosmopolit (mendunia), \\
mengutamakan kepentingan umum, cinta tanah air (patriotis), \\
bangga menggunakan bahasa dan produk Indonesia, dinamis, kerja \\
keras, dan beretos kerja.
\end{tabular}

Sumber: Diadopsi oleh penulis dari berbagai sumber.

Lebih lanjut, pendidikan karakter itu memiliki nilai-nilai etika inti (core ethical values) yang dapat ditanamkan kepada peserta didik. Matrik 1 memberikan gambaran secara rinci tentang nilai-nilai inti dari pendidikan karakter. Dalam pandangan Lickona (Lickona, 1991: 51), ada tujuh nilai karakter esensial yang dapat ditanamkan kepada peserta didik. Di pihak lain, Pusat Kurikulum Kementerian Pendidikan Dasar dan Menengah menyebutkan ada 4 (empat) kelompok nilai inti dalam pendidikan karakter (Pemerintah RI, 2010: 21), yaitu: (1) karakter yang bersumber dari olah hati, (2) karakter yang bersumber dari olah pikir, (3) karakter yang bersumber dari olah raga/kinestetika, serta (4) karakter yang bersumber dari olah rasa dan karsa.

\section{Definisi Soft Skills dan Jenis-jenisnya}

Dalam berbagai referensi ditemukan beragam definisi tentang soft skills. Menurut LaFrance (2016: 4), misalnya, soft skills didefinisikan sebagai "personal and interpersonal behaviour that develop and maximize human performance (e.g. confidence, flexibility, honesty, and integrity)" yang maksudnya adalah bahwa soft skills merupakan "Perilaku personal dan interpersonal yang mengembangkan dan memaksimalkan kinerja seseorang terkait kepercayaan diri, fleksibilitas, kejujuran dan integritas diri'. Senada dengan definisi diatas, Elfindri dkk (2011: 67), mendefinisikan soft skills sebagai "keterampilan dan kecakapan hidup, baik untuk diri sendiri, berkelompok, atau bermasyarakat, serta dengan Sang Pencipta”. Selanjutnya, Illah Sailah (2008: 19) berpendapat bahwa soft skills adalah "keterampilan seseorang dalam berhubungan dengan orang lain (inter-personal skills) dan keterampilan dalam mengatur dirinya sendiri (intra-personal skills) yang mampu mengembangkan secara maksimal unjuk kerja (performans) seseorang".

Matrik 2. Jenis-jenis Soft Skills dan Bentuknya

\begin{tabular}{ll}
\hline \multicolumn{1}{c}{ Jenis Soft Skills } & \multicolumn{1}{c}{ Bentuknya } \\
\hline & Manajemen waktu \\
& Manajemen stress \\
Personal & Manajemen perubahan \\
& Karakter transformasi \\
& Berpikir kreatif \\
& Memiliki acuan tujuan positif \\
\hline
\end{tabular}




\begin{tabular}{ll}
\hline \multicolumn{1}{c}{ Jenis Soft Skills } & \multicolumn{1}{c}{ Bentuknya } \\
\hline & Kemampuan memotivasi \\
& Kemampuan memimpin \\
Intra-personal & Kemampuan negosiasi \\
& Kemampuan presentasi \\
& Kemampuan komunikasi \\
& Kemampuan membuat relasi \\
& Kemampuan bicara di muka umum \\
\hline & Kejujuran, \\
& Tanggung jawab, \\
& Berlaku adil, \\
& Kemampuan bekerja sama, \\
& Kemampuan beradaptasi, \\
Gabungan antara Personal dan & Kemampuan berkomunikasi, \\
Intra-personal & Toleran, \\
& Hormat terhadap sesama, \\
& Kemampuan mengambil keputusan, \\
& dan Kemampuan memecahkan masalah \\
\hline
\end{tabular}

Sumber: Diadopsi oleh penulis dari berbagai sumber.

Berdasarkan definisi di atas diperoleh tiga catatan penting. Pertama, bahwa pada dasarnya soft skills merupakan kemampuan yang sudah melekat pada diri seseorang, tetapi dapat dikembangkan dengan maksimal dan dibutuhkan dalam dunia pekerjaan sebagai pelengkap dari kemampuan hard skills. Kedua, soft skills dibedakan menjadi dua macam, yaitu: soft skills yang terkait dengan personal dan soft skills yang terakait dengan intra personal. Condoh soft skills personal adalah kemampuan mengendalikan emosi dalam diri, dapat menerima nasehat orang lain, mampu memanajemen waktu, dan selalu berpikir positif. Sementara itu, contoh soft skills intra personal adalah kemampuan berhubungan atau berinteraksi dengan orang lain, bekerja sama dengan kelompok lain, dan lain lain. Ketiga, bahwa soft skills merupakan komplemen dari hard skills. Jika hard skills berkaitan dengan IQ, otak kiri serta kemampuan teknis dan akademis seseorang yang diperlukan dalam dunia kerja; maka soft skills berkaitan dengan EQ, otak kanan serta kemampuan non-teknis dan non-akademis seseorang yang diperlukan dalam kehidupan sehari-hari.

Lebih lanjut, soft skills itu memiliki jenis dan bentuk yang berbeda-beda sebagaimana yang tergambar dalam Matrik 2. Jika soft skills yang bersifat personal memiliki 6 (enam) bentuk, maka soft skills yang bersifat intra personal memiliki 7 (tujuh) bentuk. Sementara itu, kedua bentuk soft skills tersebut selanjutnya digabungkan menjadi 10 (sepuluh) bentuk (Illah Sailah: 2008: 1920).

\section{Pendekatan dan Metode Pembelajaran}

Pendekatan pembelajaran di perguruan tinggi yang paling muttakhir adalah pendekatan SCL (student centered learning). Pendekatan SCL ini menurut Rogers (1983: 183), "merupakan hasil dari transisi perpindahan kekuatan dalam proses pembelajaran, dari kekuatan dosen sebagai pakar menjadi kekuatan mahasiswa sebagai pembelajar". Dengan redaksi yang berbeda, Kember (1997: 255) mengatakan "bahwa SCL merupakan sebuah kutub proses pembelajaran yang menekankan mahasiswa sebagai pembangun pengetahuan sedangkan kutub yang lain adalah dosen sebagai agen yang memberikan pengetahuan". Dari dua definisi tersebut dapat dipahami bahwa SCL adalah suatu model pembelajaran yang menempatkan peserta didik sebagai pusat dari proses belajar. Model pembelajaran ini berbeda dari model belajar konvensional yang menekankan pada transfer pengetahuan dari dosen ke mahasiswa yang relatif bersikap pasif. 
Dalam kajian ini SCL dipilih sebagai pendekatan dalam perkuliahan dengan alasan bahwa SCL sangat cocok untuk perkuliahan berbasis soft skills. Pendekatan SCL telah menekankan pada minat, kebutuhan dan kemampuan individu, menjanjikan model belajar yang menggali motivasi intrinsik untuk membangun masyarakat yang suka dan selalu belajar. Model belajar ini sekaligus dapat mengembangkan kualitas sumber daya manusia yang dibutuhkan masyarakat seperti kreativitas, kepemimpinan, rasa percaya diri, kemandirian, kedisiplinan, kekritisan dalam berpikir, kemampuan berkomunikasi dan bekerja dalam tim, keahlian teknis, serta wawasan global untuk dapat selalu beradaptasi terhadap perubahan dan perkembangan.

Sebagai konsekuensi dari penerapan pendekatan SCL dalam perkuliahan, ada beberapa metode yang dapat digunakan dalam pendekatan SCL, yaitu: (1) Small Group Discussion, (2) Role-Play \& Simulation, (3) Case Study, (4) Discovery Learning, (5) Self-Directed Learning, (6) Cooperative Learning, (7) Collaborative Learning, (8) Contextual Instruction, (9) Project Based Learning, dan (10) Problem Based Learning and Inquiry (Illah Sailah: 2008: 36). Semua metode di atas menuntut partisipasi aktif dari mahasiswa di satu sisi, dan pada sisi yang lain dosen dituntut untuk berperan sebagai fasilitator dan mitra mahasiswa dalam proses pembelajaran. Harus diakui bahwa semua metode di atas sangat relevan dengan kondisi ekstemal masa kini yang menjadi tantangan bagi mahasiswa untuk mampu mengambil keputusan secara efektif terhadap problematika yang dihadapinya. Melalui penerapan metode tersebut mahasiswa harus berpartisipasi secara aktif, selalu ditantang untuk memiliki daya kritis, mampu menganalisis dan dapat memecahkan masalah-masalahnya sendiri.

\section{Hasil Dan Pembahasan}

\section{Soft Skills dan Pengembangan Karakter Mahasiswa}

Beberapa data yang diperoleh dalam kajian ini menunjukkan bahwa karakter mahasiswa dapat dikembangkan melalui kegiatan kemahasiswaan berbasis soft skills. Adapun jenis data yang disajikan dalam pembahasan ini adalah kegiatan kemahasiswaan di UGM, UNAIR, ITS, dan IPB yang dijadikan sarana untuk pengembangan karakter mahasiswa berbasis soft skills.

Kegiatan kemahasiswaan di UGM yang dijadikan sarana untuk pengembangan soft skills sejak tahun 2005 diarahkan:

"Untuk meningkatkan thinking skills, learning skills dan living skills. Program ini diberikan kepada mahasiswa baru pada masa orientasi kampus. Learning Skills adalah keterampilan yang digunakan agar mahasiswa selalu dapat mengembangkan diri melalui proses belajar yang berkelanjutan. Thinking Skills adalah keterampilan yang dibutuhkan pada saat mahasiswa berpikir untuk memecahkan masalah di kehidupan sehari-hari. Living skills adalah keterampilan yang dibutuhkan untuk beradaptasi dalam kehidupan sehari-hari” (Ilah Sailah, dkk. 2008: 44).

Kegiatan kemahasiswaan di Universitas Airlangga dan Institut Teknologi Surabaya (ITS), keduanya berada di Surabaya, juga dijadikan sarana untuk mengembangkan karakter mahasiswa berbasis soft skills.

"Universitas Airlangga beberapa tahun terakhir ini memiliki program Mahasiswa Unggulan. Mahasiswa yang menjadi peserta adalah mahasiswa pilihan dari berbagai fakultas yang 
dinyatakan berprestasi. Program ini diisi dengan caring and sharing antara pakar/praktisi dengan mahasiswa seputar isu-isu aktual. Keuntungan program ini adalah dapat menjaring future leader dan membinanya dari sejak awal sebelum mereka lulus. Kemampuan yang ingin ditingkatkan adalah wawasan yang luas, saling menghormati satu sama lain, berjiwa entrepreneur, berfikir kreatif dan kemampuan belajar yang lebih baik" (Ilah Sailah, dkk. 2008: 45).

Sementara itu, di ITS telah dilakukan kegiatan yang secara tidak langsung akan meningkatkan soft skills mahasiswa melalui center for entrepreneurship development, atau kegiatan business gathering.

"Kegiatan ini dimaksudkan untuk
meningkatkan jiwa entrepreneurial,
diantaranya berani mengambil resiko,
berani bermimpi, pantang menyerah
dan selalu bersemangat. Sebenarnya
kegiatan pengembangan soft skills tidak
akan optimal bila hanya dilakukan
melalui pelatihan, seminar dan
workshop. Pengembangan soft skills
harus dipraktekkan berulang-ulang dan
didampingi oleh mentor" (Ilah Sailah,
dkk. 2008: 45).

Terakhir, berbagai kegiatan Unit Kegiatan Mahasiswa yang diselenggarakan di IPB, telah banyak memuat materi soft skills yang dapat dikembangkan oleh mahasiswa. Hal ini akan berhasil guna jika program yang digulirkan lebih terarah untuk mengembangkan atribut tertentu sesuai dengan kebutuhan populasinya.

"Unit kegiatan karate saja, apabila dihayatidan benar-benarditujukan untuk pengembangan soft skills mahasiswa, dapat diarahkan untuk memperkuat atribut komitmen, bersemangat, mandiri, dan ketangguhan. Kegiatan pelatihan harus terprogram dengan baik, ada durasi, capaian dan keberlanjutan. Apakah pelatihan akan diarahkan pada transformasi keyakinan, motivasi, karakter, impian. Lantas tidak hanya berhenti di pelatihan tanpa adanya coaching oleh para coach yang tangguh, sampai akhirnya dalam durasi tertentu akan terjadi transformasi diri yang seutuhnya" (Ilah Sailah, dkk. 2008: 46).

Memperhatikan jenis data di atas di satu sisi dan kajian teori di atas pada sisi yang lain, dapat ditegaskan bahwa para dosen dapat mengembangkan karakter mahasiswa di perguruan tinggi melalui kegiatan kemahasiswaan, dengan dua alternatif teori, yaitu: (1) teori nilai pendidikan karakter yang dikemukakan oleh Thomas Lickona atau Pusat Kurikulum Kementerian Pendidikan dan Kebudayaan RI; serta (2) teori jenis soft skills dan bentuk-bentuknya yang dikemukakan oleh Illah Sailah, baik yang bersifat personal, intra personal atau gabungan dari keduanya.

Jika teori Lickona yang dipilih, maka pengembangan karakter mahasiswa dapat dilakukan dengan 7 (tujuh) nilai pendidikan karakter, yaitu: (1) ketulusan hati atau kejujuran, (2) belas kasih, (3) kegagahberanian, (4) kasih sayang, (5) kontrol diri, (6) kerja sama, dan (7) kerja keras. Sementara itu, jika yang dipilih teori Pusat Kurikulum Kementerian Pendidikan Dasar dan Menengah, maka pengembangan karakter mahasiswa dapat dilakukan dengan 4 (empat) kelompok nilai inti dalam pendidikan karakter, yaitu: (1) karakter yang bersumber dari olah hati: beriman dan bertakwa, jujur, amanah, adil, tertib, taat aturan, bertanggung jawab, berempati, berani mengambil resiko, pantang menyerah, rela berkorban, dan berjiwa patriotik; (2) karakter yang bersumber dari olah pikir: cerdas, kritis, kreatif, inovatif, ingin tahu, produktif, berorientasi Ipteks, dan reflektif; (3) karakter yang bersumber dari olah raga/ kinestetika: bersih, sehat, sportif, tangguh, andal, berdaya tahan, bersahabat, kooperatif, 
determinatif, kompetitif, ceria, dan gigih; serta (4) karakter yang bersumber dari olah rasa dan karsa: kemanusiaan, saling menghargai, gotong royong, kebersamaan, ramah, hormat, toleran, nasionalis, peduli, kosmopolit (mendunia), mengutamakan kepentingan umum, cinta tanah air (patriotis), bangga menggunakan bahasa dan produk Indonesia, dinamis, kerja keras, dan beretos kerja.

Di pihak lain, jika teori jenis soft skills dan bentuk-bentuknya yang dikemukakan oleh Illah Sailah di pilih, baik yang bersifat personal, intra personal atau gabungan dari keduanya, maka pengembangan karakter mahasiswa dapat dilakukan dengan 10 (sepuluh) jenis soft skills dan bentukbentuknya, yaitu: (1) kejujuran, (2) tanggung jawab, (3) berlaku adil, (4) kemampuan bekerja sama, (5) kemampuan beradaptasi, (6) kemampuan berkomunikasi, (7) toleran, (8) hormat terhadap sesama, (9) kemampuan mengambil keputusan, dan (10) kemampuan memecahkan masalah. Kesepuluh jenis soft skills di atas merupakan gabungan dari keterampilan mahasiswa dalam mengatur dirinya sendiri dan keterampilan dalam berhubungan dengan orang lain. Lebih lanjut dinyatakan bahwa kesepuluh jenis soft skills inilah yang berkontribusi sekitar $80 \%$ terhadap keberhasilan mahasiswa dalam berbagai jenis profesi dan pekerjaan.

\section{Soft Skills sebagai Basis Pembelajaran Karakter di Perguruan Tinggi}

Beberapa data yang diperoleh dalam kajian ini menunjukkan bahwa soft skills dapat dijadikan materi untuk pengembangan karakter mahasiswa di perguruan tinggi. Adapun jenis data yang disajikan dalam pembahasan ini berupa pendapat para pakar yang menegaskan bahwa karakter mahasiswa dapat dikembangkan oleh para dosen melalui kegiatan perkuliahan berbasis soft skills. Jenis data yang disajikan dalam pembahasan ini adalah pendapat Nicole Fallon, Felix Day, Prijosaksono, dan Christoph Hansert.
Nicole Fallon (2015: 3)-seorang trainer soft skills di New York, misalnya, berpendapat:

"Bahwa soft skills mahasiswa itu bukan hanya dapat dikembangkan melainkan juga dapat diajarkan oleh para dosen di perguruan tinggi". Senada dengan pendapat ini, Felix Day menyatakan "bahwa mahasiswa itu memerlukan soft skills untuk keberhasilannya pada karir dan dunia kerja, oleh karena itu materi soft skills perlu diajarkan kepada para mahasiswa di perguruan tinggi" (Felix Day, 2012: 5).

Data lain yang menegaskan bahwa soft skills itu dapat dijadikan materi untuk pengembangan karakter mahasiswa di perguruan tinggi adalah pendapat Prijosaksono dan Christoph Hanssert. Prijosaksono dalam buku terbaru yang berjudul The Power of Transformation (2005: 170) menuliskan bahwa:

"Transformasi diri 90 hari akan mampu membangun kebiasaan-kebiasaan baru yang lebih baik. Dalam buku itu juga diuraikan bahwa ada 5 prinsip transformasi yaitu: (1) meyakini dan mendayagunakan kekuatan dan anugrah Tuhan dalam diri, (2) membuat pilihan dan keputusan dalam diri, (3) melakukan kebiasaan-kebiasaan baik secara terusmenerus dalam kehidupan ini, (4) mampu membangun interaksi dengan orang lain, dan (5) mampu bekerja secara sinergis dan kreatif dengan orang lain dalam organisasi"”.

Di pihak lain, Christoph Hansert, seorang pakar dalam bidang pengembangan pendidikan dari Jerman (dalam Illah Sailah, 2008: 46), menyarankan:

"Agar pengembangan soft skills untuk mahasiswa Indonesia dilakukan 
dengan cara menjalin jejaring kerja (networking) dosen Indonesia dengan dosen luar negeri yang melibatkan mahasiswa, misalnya dalam bidang penelitian. Dengan jejaring ini, mau tidak mau mahasiswa akan terpaksa berkomunikasi tulisan dengan menggunakan bahasa asing. Suatu saat mahasiswa ini difasilitasi untuk bertemu bertukar pikiran, saling menghargai pendapat, mempelajari budaya orang lain dan belajar bekerjasama dalam tim".

Memperhatikan jenis data di atas di satu sisi dan kajian teori di atas pada sisi yang lain, dapat ditegaskan bahwa karakter mahasiswa di perguruan tinggi dapat dikembangkan oleh dosen melalui kegiatan perkuliahan berbasis soft skills. Kegiatan perkuliahan ini terdiri atas tiga alternatif cara, yaitu: (1) lewat kegiatan pembelajaran mata kuliah yang berdiri sendiri, (2) lewat penggunaan metode perkuliahan dengan mengintegrasikannya ke dalam mata kuliah tertentu, dan (3) lewat menjadikan dosen sebagai role model bagi para mahasiswa. Ketiga cara tersebut akan dibahas pada uraian-uraian berikut.

Pertama, pembelajaran soft skills dapat dilakukan melalui mata kuliah yang berdiri sendiri. Jika cara ini yang dipilih, maka sang dosen harus memastikan bahwa dalam struktur kurikulumnya ada mata kuliah soft skills. Pada bagian ini, proses pembelajaran perlu diarahkan pada 2 aspek pembelajaran, yaitu: tujuan dan materi yang berbasis soft skills. Pada aspek tujuan, dosen harus memastikan bahwa tujuan perkuliahan yang harus dicapai oleh para mahasiswa adalah gabungan dari tiga ranah pembelajaran, yaitu: ranah kognitif, ranah psikomotorik, dan ranah afektif. Oleh karena sifatnya gabungan, maka tujuan perkuliahan bukan hanya menekankan pada hafalan dan penguasaan jenis soft skills dan bentukbentuknya, juga bukan hanya menekankan pada keterampilan mempraktikkan jenis soft skills dan bentuk-bentuknya dalam kehidupan nyata mahasiswa, melainkan juga memfokuskan pada kepribadian para mahasiswa, terutama terkait penumbuhan rasa percaya diri sehingga menjadi manusia utuh yang memiliki kemantapan emosional dan intelektual, yang mengenal dirinya, yang mengendalikan dirinya dengan konsisten dan memiliki rasa empati.

Lebih lanjut, pada aspek materi, para dosen dapat menjadikan jenis-jenis soft skills sebagaimana yang dikemukakan oleh Illah Sailah di atas sebagai topik pembahasan inti dalam perkuliahannya secara berurutan. Pada setiap waktu tatap muka dosen dapat menyampaikan satu atau dua materi soft skills dengan memperkaya pesan moral di dalamnya, baik pada saat awal membuka perkuliahan atau menutup pertemuan. Cara ini disebut Message of the week (MOW). Pesan yang disampaikan dapat berupa katakata mutiara dari berbagai sumber dengan pemaknaannya dalam berkehidupan. Jika satu semester ada 14 kali pertemuan, dan setiap mahasiswa minimal mengambil 6 mata kuliah, maka paling tidak dalam satu semester mereka akan diinspirasi dengan 84 kata-kata dan cerita yang membangun moral. Jika hal ini dilakukan secara konsisten oleh para dosen, maka diyakini dapat memperbaiki pola pikir, sikap dan perilaku mahasiswa yang berbasis soft skills.

Kedua, pembelajaran soft skills lewat metode perkuliahan dan mengintegrasikannya ke dalam mata kuliah tertentu. Jika cara ini yang dipilih, para dosen perlu menekankan pada dua aspek, yaitu: aspek pendekatan dan aspek metode perkuliahan. Pada aspek pendekatan, dosen perlu menggunakan pendekatan SCL sebagai pilihan utama dalam proses perkuliahan. Pendekatan ini berkonsekuensi pada perubahan cara pandang dalam proses pembelajaran di perguruan tinggi. Ada tiga perubahan cara pandang dalam perkuliahan, yaitu: (1) dari sisi pengetahuan, dulu pengetahuan dipandang sebagai sesuatu yang sudah jadi, tinggal dipindahkan dari dosen ke mahasiswa. Namun sekarang 
pengetahuan adalah hasil konstruksi atau hasil transformasi seseorang yang belajar; (2) dulu belajar adalah menerima pengetahuan (pasif-reseptif), sekarang belajar adalah mencari dan mengkonstruksi (membentuk) pengetahuan aktif dan spesifik; serta (3) dulu mengajar adalah menjalankan sebuah instruksi yang telah dirancang, namun kini menjalankan berbagai strategi yang membantu mahasiswa untuk dapat belajar.

Adapun pada aspek metode, para dosen harus menggunakan berbagai metode dalam proses perkuliahan. Lewat beragam metode, dosen dapat menginternalisasikan dan mengimplementasikan soft skills dalam proses perkuliahan. Berbagai metode telah banyak ditemukan oleh peneliti pendidikan sebagaimana yang dijelaskan dalam kajian teori di atas, dosen tinggal memilih mana yang cocok dan relevan untuk diterapkan pada mata kuliah yang diampu.

Dalam satu mata kuliah dapat diterapkan pengembangan softskills lebih dari dua atribut sekaligus. Misalnya melatih berpikir analitis, kreatif, berfikir kritis dan manajemen waktu dapat dilakukan pendekatan SCL dengan menggunakan Problem based Learning atau studi kasus. Sementara itu, penerapan atribut soft skills di ruang kelas dapat dilakukan dengan memperbanyak tugas presentasi, diskusi kelompok, sampai role play. Lebih jauh, jika mata kuliah tersebut mengharapkan peningkatan atribut soft skills komunikasi, kerjasama kelompok, dan berfikir analitis dan kritis, maka diskusi kelompok diikuti dengan penyajian lisan akan menjadi pilihan untuk diterapkan. Dengan demikian pendekatan pembelajaran SCL belum tentu cocok antara satu mata kuliah dengan mata kuliah lainnya.

Berbagai metode di atas meniscayakan perlunya dapat membuat proses pembelajaran lebih menarik minat dan menyenangkan. Peran dosen dalam hal ini adalah: (1) membangun proses dialog, (2) menangani dinamika kelompok, (3) terlibat dengan motivasi mahasiswa, (4) mengintroduksikan berpikir kritis, dan (5) memberdayakan kurikulum tersembunyi.
Ketiga, melalui dosen role model bagi mahasiswanya. Yang dimaksud dosen role model di sini adalah "Seorang dosen yang berfungsi sebagai contoh, yang perilakunya ditiru orang lain" (Kamus Online Wikipedia, 2016). Mahasiswa akan mudah mengikuti kata-kata dosennya, jika ada contoh riil darinya. Jika seorang dosen berkata pentingnya dialog dalam memecahkan permasalahan tertentu, misalnya, namun sang dosen tidak pernah sedikitpun melakukan langkah tersebut. maka otomatis mahasiswa akan mengabaikan pernyataannya tersebut.

Jika cara ini yang dipilih, para dosen harus siap menjadi teladan dalam penerapan soft skills dalam kehidupan nyata di lingkungan perguruan tinggi. Harus diakui bahwa pengembangan soft skills akan efektif jika para dosen siap menjadi role model bagi mahasiswanya. Misalnya jika akan menegakkan disiplin mahasiswa, maka contoh baik dapat didemonstrasikan kepada mahasiswa oleh dosennya. Apabila dosen menginginkan mahasiswa datang tepat waktu, maka dosen harus duluan datang ke kelas. Apabila mahasiswa diminta untuk selalu menjaga kebersihan kelas, maka dosen harus mampu menghapus papan tulis setelah selesai kuliah. Apabila dosen berjanji akan mengembalikan tugas dalam tiga minggu, maka jangan sampai mengembalikan 5 minggu kemudian.

Role model dosen dapat diperlihatkan dengan saling menghargai dengan teman sejawat di depan mahasiswa. Sebaliknya, saling menjelekkan antar dosen di depan mahasiswa patut dihindari. Jika dosen kalah dalam satu kompetisi, jangan sampai mahasiswa menjadi tumpahan keluhan rasa kekesalan dosen dengan menyalahkan orang lain. Sering-seringlah memberikan pujian kepada mahasiswa di depan mahasiswa lainnya jika mahasiswa mampu mencapai prestasi, baik prestasi akademik mupun prestasi non-akademik.

\section{Simpulan}

Kajian ini menghasilkan dua simpulan penting. Pertama, para dosen 
dapat menggunakan soft skills untuk mengembangkan karakter lulusan perguruan tinggi lewat kegiatan kemahasiswaan, dengan dua alternatif teori, yaitu: (1) teori nilai pendidikan karakter yang dikemukakan oleh Thomas Lickona atau Pusat Kurikulum Kementerian Pendidikan dan Kebudayaan RI; serta (2) teori jenis soft skills dan bentukbentuknya yang dikemukakan oleh Illah Sailah, baik yang bersifat personal, intra personal atau gabungan dari keduanya. Jika teori Lickona yang dipilih, maka kegiatan kemahasiswaan perlu diarahkan pada 7 (tujuh) nilai pendidikan karakter. Jika teori Pusat Kurikulum Kementerian Pendidikan dan Kebudayaan RI yang dipilih, maka kegiatan kemahasiswaan perlu diarahkan pada 4 (empat) kelompok nilai inti dalam pendidikan karakter. Sementara itu, jika yang dipilih adalah teori jenis soft skills dan bentuk-bentuknya yang dikemukakan oleh Illah Sailah, baik yang bersifat personal, intra personal atau gabungan dari keduanya; maka kegiatan kemahasiswaan perlu diarahkan pada 10 (sepuluh) jenis soft skills dan bentuk-bentuknya.

Kedua, para dosen dapat menjadikan soft skills sebagai basis pembelajaran karakter di perguruan tinggi, yang terdiri atas tiga alternatif cara, yaitu: (1) lewat kegiatan pembelajaran mata kuliah yang berdiri sendiri, (2) lewat penggunaan metode perkuliahan dengan mengintegrasikannya ke dalam mata kuliah tertentu, dan (3) lewat menjadikan dosen sebagai role model bagi para mahasiswa. Jika yang dipilih cara pertama, maka para dosen harus memastikan bahwa dalam struktur kurikulumnya ada mata kuliah soft skills. Proses pembelajarannya perlu diarahkan pada 2 aspek pembelajaran, yaitu: tujuan dan materi yang berbasis soft skills. Jika yang dipilih cara kedua, maka para dosen perlu menekankan pada dua aspek, yaitu: aspek pendekatan dan aspek metode perkuliahan. Pendekatan yang digunakan dalam perkuliahan adalah pendekatan SCL (student centered learning), sedangkan metode perkuliahannya adalah: (1) Small Group Discussion, (2) Role-Play \& Simulation, (3) Case Study, (4) Discovery Learning, (5) Self-Directed Learning, (6) Cooperative Learning, (7) Collaborative Learning, (8) Contextual Instruction, (9) Project Based Learning, dan (10) Problem Based Learning and Inquiry.

\section{Daftar Rujukan}

Creswell, John W. 2008. Research Design Pendekatan Kualitatif, Kuantitatif, dan Mixed, Edisi Ketiga. Yogyakarta: Pustaka Pelajar.

Day, Flex. 2012. Our Students Need Soft Skills. Mali: Delta College Press.

Ditjen Dikti RI. 2004. Strategi Jangka Panjang Pendidikan Tinggi 2003-2010.

Elfindri, dkk., 2010. Soft Skills untuk Pendidik. T.k.: Baduose Media.

Fallon, Nicole. 2015. Soft Skills Matter: Can They Be Taught? New York: Business News Daily Assistant Editor.

Given, Lisa M. 2008. The Sage Encyclopedia of Qualitative Research Methods, Singapore: Sage Publications.

https://en.wikipedia.org/wiki/Role_model

Kember, D. 1997. "A reconceptualisation of the research into university academics conceptions of teaching". Learning and Instruction 7(3), 255-275.

LaFrance, Aricia E. Helping Students Cultivate Soft Skills. Diakses pada 15 Desember 2016, dari http://www.ncda.org/aws/NCDA/pt/sd/news_article/7010/_PARENT/layout_ details_cc/false

50 I ishraqi, Volume 1 No. 1 Januari 2017 ... (40-51) 
Moleong, Lexy J. 2007. Metodologi Penelitian Kualitatif. Bandung: Remaja Rosda Karya.

Pemerintah Republik Indonesia. 2003. Undang-Undang Sistem Pendidikan Nasional (Sisdiknas) Nomor 20 Tahun 2003. Jakarta: Pemerintah Republik Indonesia.

Prijosaksono, A. M. Marlan. 2005. The Power of Transformation. Penerbit Elex Media Komputindo. Jakarta.

Ramli, T. 2003. Pendidikan Karakter. Jakarta: PT Bestari Muara Murni.

Rogers, C. R. 1983. "The politics of education". In Freedom to Learn for the 80's. Ohio: Charles E. Merrill Publishing Company.

Sailah, Ilah dkk. 2008. Pengembangan Soft Skills dalam Proses Pembelajaran di Perguruan Tinggi. Jakarta: Direktorat Akademik, Direktorak Jenderal Pendidikan Tinggi, Departemen Pendidikan Nasional.

Santrock, John W. 2007. Psikologi Pendidikan. Ed. Kedua. Jakarta: Kencana Press.

Sugiyono. 2012. Memahami Penelitian Kualitatif. Bandung: ALFABETA.

Suyanto, Ph.D. 2010. Model Pembinaan Pendidikan Karakter Di Lingkungan Sekolah. Jakarta: Dirjen Dikdasmen Direktorat Pendidikan Dasar Dan Menengah Kementerian Pendidikan Nasional. 